\title{
Impact of Corporate Governance on Corporate Financial Performance
}

\author{
Priyanka Aggarwal ${ }^{1}$ \\ I'Assistant Professor, Department of Commerce, Shaheed Bhagat Singh College, University of Delhi, India \\ \& \\ Research Scholar, Department of Commerce, Delhi School of Economics, University of Delhi, India)
}

\begin{abstract}
Corporate governance is the new buzz-word in corporate world these days. It is viewed as a moral duty. It involves promoting the compliance of law in letter and spirit and demonstrating ethical conduct. The relationship between corporate governance and financial performance has caught wide attention of researchers in the last decade. Numerous researches have been conducted in past to investigate this linkage, but there has been lack of conclusive evidence. The results obtained from existing researches have been mixed. In this paper, we attempt to investigate the impact of corporate governance on corporate financial performance in an Indian context, using a sample of 20 companies listed on S\&P CNX Nifty 50 Index. Various tests like - regression, correlation, $t$-test and F-test have been performed using secondary data over a period of two years from $F Y$ 2010-11 to FY 2011-12 to study this linkage. We have also controlled for size of firm. We find that governance ratings have positive and significant impact on corporate financial performance. But like any other research, the present study is also subject to certain limitations, which should be considered while using the results of this study and the future researchers should attempt to overcome these limitations.
\end{abstract}

Keywords: Business Ethics, Compliance, Corporate Financial Performance, Corporate Governance, Stakeholder Engagement, Value Creation.

\section{Introduction}

Corporate Governance in simple words means the extent to which companies are run in an open and honest manner. The Cadbury Committee of U.K. in 2002 defined corporate governance as - the system by which companies are directed and controlled. The essence of the corporate world lies in promoting transparency and accountability and in fulfilling the fair expectations of all the stakeholders. Corporate governance is one such tool to achieve this goal and to safeguard the interests of various stakeholder groups. It involves promoting the compliance of law in letter and spirit, and demonstrating ethical conduct. The framework of corporate governance encourages efficient use of resources and also requires accountability for the stewardship of those resources. The three key constituents of corporate governance are - Shareholders, Board of Directors and Management.

The area of corporate governance has acquired heightened attention in the last decade because of various notable corporate scandals and collapses, such as Enron, WorldCom, Satyam, etc. which involved unethical business practices. It is often said that corporate governance and value creation go hand in hand. Unless a corporation embraces and demonstrates ethical conduct, it will not be able to succeed. Various researches have been conducted to investigate the relationship between corporate governance and financial performance, but the results have been mixed and inconclusive. In this paper, we examine and analyze the impact of corporate governance on financial performance of firm in an Indian context.

\section{Objectives of the Study}

This paper aims to achieve the following objectives: 1) To provide an overview of various components of corporate governance; 2) To provide literature review on the relationship between corporate governance and corporate financial performance; and 3) To examine the impact of corporate governance on financial performance of firm in an Indian context through multiple regression, correlation, t-test and F-test.

\section{Components of Corporate Governance}

3.1 Board Size: The size of board is believed to have a significant impact on firm's performance; which is usually observed to be positive.

3.2 Independence of Board from Management: It is widely believed that independent directors play a significant role in monitoring and advising the company's management. They are required to safeguard overall organizational and stakeholders interest. 
3.3 Separation of CEO and Chairman: Conflict of interest, concentration of power and reduced board independence are usually observed when the roles of CEO and Chairman of the board are exercised by the same individual.

3.4 Financial Expertise of Directors: Directors should be financially literate, so that they can better understand the implications of decisions taken by management and thus, lead to better \& effective controlling.

3.5 Number of Board Meetings: Board members should meet sufficient number of times. Very few meetings show lack of interest on the part of Board, while too frequent meetings indicate some trouble in the organization.

3.6 Role of External Auditors: The external auditor should be competent and independent enough to detect and report frauds and manipulations in corporate reports. Simultaneous provision of both audit and non-audit services by external auditors affects effectiveness of audit. Amount of audit fees is also relevant.

3.7 Committees of the Board: Board committees add to effectiveness of board by exercising better control over management decisions. These include -

a)Audit committee: High-profile corporate scams have heightened the need for an effective audit committee.

Frequent meetings and independence of audit committee can ensure credibility of corporate reports.

b)Remuneration committee: A board remuneration committee helps in deciding the suitable amount of remuneration for the top level executives like CEO.

c) Nomination committee: The nomination committee evaluates the skills, knowledge, and expertise needed to become a director and identifies the suitable candidates.

\section{Literature Review}

A large number of studies have examined the relationship between corporate governance and firm performance. Most of the studies suggested positive correlation. But despite the intuition that good governance leads to good performance by firm, there has been lack of conclusive evidence on this linkage and the results have been mixed (Pande, 2011) [1].

Brown and Caylor (2004) [2] determined that board composition was the most important driving factor among the core factors of Corporate Governance Quotient (CGQ). They also found positive correlation between industry-adjusted CGQ scores and financial performance measures - shareholder returns, profitability, and dividend payouts and yields. Van de Velde et al. (2005) [3] analyzed the linkage of corporate governance ratings and financial performance, and found positive but not significant relationship between them. This observation is consistent with the findings of Gompers et al. (2003) [4], who further found that firms with stronger governance structure and shareholder rights enjoy higher firm value, profits and sales growth. Governance Metrics International and Byun (2006) [5] investigated the association between corporate governance ratings and financial performance, and found that companies rated in the top $10 \%$ of GMI's global database achieved a higher ROE, ROA and Return on Capital (ROC) than companies in bottom $10 \%$. Selvaggi and Upton (2008) [6] found that better governed firms yield higher risk-adjusted returns. They strongly emphasized that enhanced corporate governance is the cause of enhanced performance and not vice versa. Eisenhofer (2010) [7] concluded that, "good corporate governance fosters long-term profitability and it does, in fact, pay."

However, Core et al. (2006) [8]; and Statman and Gluskhov (2009) [9] found no significant association between governance and financial performance. Azim (2012) [10] used Structural Equation Modeling (SEM) and observed that some governance mechanisms have positive covariance, while some have negative covariance. Thus, he arrived at no consistent and significant relationship between governance mechanisms and financial performance (as proxied by ROE, ROA, Market to Book Value Ratio, Price Earnings Ratio and Dividend Yield).

Thus, we observe that some of the existing studies suggest positive and significant relationship; some suggest positive but insignificant relationship; while some studies suggest no significant association between corporate governance and corporate financial performance. Thus, existing literature provides mixed and inconclusive results and hence, further empirical examination is required to be done in this context to arrive at conclusive results.

\section{Hypothesis}

Based on theoretical arguments and review of literature, the following hypothesis has been formulated: (Null Hypothesis) Ho: Governance rating of company has no impact on its financial performance. (Alternate Hypothesis) Ha: Governance rating of company has an impact on its financial performance.

\section{Research Methodology}

Various tests like - multiple regression, correlation, t-test and F-test have been performed using IBMSPSS Statistics software to investigate the impact of corporate governance on financial performance using 
secondary and cross-sectional data. The average of data over a period of two years from FY 2010-11 to FY 2011-12 has been used for analysis.

\subsection{Sample Selection}

The sample comprises of 20 Indian companies, which are non-financial companies; listed on the NSE; which have continuously been included in NIFTY 50 Index during $1^{\text {st }}$ April, 2010 to $31^{\text {st }}$ March, 2012, with availability of required financial and governance ratings data; and which have at least once issued Sustainability/CSR Report as per GRI guidelines.

\subsection{Variable Description \& Data Sources}

Four Accounting-based measures - Return on Assets (ROA), Return on Equity (ROE), Return on Capital Employed (ROCE) and Profit before Tax (PBT) - have been used as proxies for financial performance. Accounting-based measures of financial performance have been chosen because the audited accounting data tends to provide true and fair view of company and is not influenced by market perceptions and is thus considered less noisy in comparison to market based indicators like stock returns, share prices, etc. (Lopez et al., 2007) [11].

The governance ratings of companies have been used as proxy for corporate governance performance. We control for environmental, community-related and employee-related performance of companies, which are likely to influence governance of companies. We also control for size of company by using Natural Log of Total Assets.

The financial data has been obtained from website "Moneycontrol.com". The governance, community, employee and environment ratings data have been obtained from "CSRHub database", which claims to be world's largest corporate sustainability ratings database and principally adheres to GRI guidelines. CSRHub rates governance of companies mainly along three indicators, namely, Board, Leadership Ethics and Transparency \& Reporting.

\subsection{Research Model}

We study the impact of governance rating of firm (independent variable - GOV) on the financial performance of firm (dependent variable - ROA, ROE, ROCE and PBT); while controlling for size of firm (SIZE) and its performance along employees-related (EMP), community-related (COM) and environmental (ENV) dimensions. The following four equations have been formulated for analysis:

$$
\begin{aligned}
& \mathrm{ROA}=\mathrm{c}+\mathrm{b}_{1} \cdot \mathrm{GOV}+\mathrm{b}_{2} \cdot \mathrm{EMP}+\mathrm{b}_{3} \cdot \mathrm{ENV}+\mathrm{b}_{4} \cdot \mathrm{COM}+\mathrm{b}_{5} \cdot \mathrm{SIZE} \\
& \mathrm{ROE}=\mathrm{c}+\mathrm{b}_{1} \cdot \mathrm{GOV}+\mathrm{b}_{2} \cdot \mathrm{EMP}+\mathrm{b}_{3} \cdot \mathrm{ENV}+\mathrm{b}_{4} \cdot \mathrm{COM}+\mathrm{b}_{5} \cdot \mathrm{SIZE} \\
& \text { ROCE }=c+b_{1} \cdot \text { GOV }+b_{2} \cdot \text { EMP }+b_{3} \cdot \text { ENV }+b_{4} \cdot C O M+b_{5} \text {.SIZE } \\
& \mathrm{PBT}=\mathrm{c}+\mathrm{b}_{1} \cdot \mathrm{GOV}+\mathrm{b}_{2} \cdot \mathrm{EMP}+\mathrm{b}_{3} \cdot \mathrm{ENV}+\mathrm{b}_{4} \cdot \mathrm{COM}+\mathrm{b}_{5} \cdot \mathrm{SIZE}
\end{aligned}
$$

\section{Data Analysis \& Interpretation}

The descriptive statistics for variables used in this study have been shown in TABLE -1 below.

TABLE - 1: Descriptive Statistics

\begin{tabular}{|c|c|c|c|c|c|}
\hline Particulars & ROA (\%) & ROE (\%) & ROCE (\%) & PBT (in Rs. Cr.) & GOV (\%) \\
\hline Mean & 15.923 & 19.440 & 25.663 & 8125.417 & $\mathbf{4 9 . 8 5}$ \\
\hline Median & 12.219 & 14.092 & 16.790 & 5556.093 & 50.75 \\
\hline Std. Dev. & 11.036 & 16.517 & 24.029 & 8168.097 & 8.604 \\
\hline Observations & 20 & 20 & 20 & 20 & 20 \\
\hline
\end{tabular}

From TABLE - 1, we observe that the mean value of Governance ratings is only $49.85 \%$, which is even less than $50 \%$. This highlights the need to improve the governance structure of Indian companies, so as to achieve higher governance ratings.

The results of regression analysis regarding impact of governance ratings on financial performance of firm have been summarized in TABLE - 2 below. 
TABLE - 2: Summary of Results

\begin{tabular}{|c|c|c|c|c|c|c|c|}
\hline Particulars & $\mathbf{R}$ & $\mathbf{R}^{\mathbf{2}}$ & $\begin{array}{c}\text { Adjusted } \\
\mathbf{R}^{\mathbf{2}}\end{array}$ & $\mathbf{F}$ & $\begin{array}{c}\text { Significance } \\
\text { of } \mathbf{F}\end{array}$ & $\begin{array}{c}\text { Beta } \\
\text { Coefficient for } \\
\mathbf{G O V} \\
\left(\mathbf{b}_{\mathbf{1}} \mathbf{)}\right.\end{array}$ & $\mathbf{p}$-value \\
\hline ROA & .730 & .533 & .367 & 3.201 & .039 & 1.381 & $.024^{*}$ \\
\hline ROE & .769 & .592 & .446 & 4.064 & .017 & 1.926 & $.025^{*}$ \\
\hline ROCE & .760 & .577 & .426 & 3.825 & .021 & 3.026 & $.018^{*}$ \\
\hline PBT & .826 & .683 & .570 & 6.036 & .004 & 827.701 & $.027^{*}$ \\
\hline
\end{tabular}

* Significant at 5\% level of Significance

VIII. Findings \& Conclusions

We make following findings and conclusions from observation of data given in TABLE - 2:

- The coefficients of determination $\left(\mathrm{R}^{2}\right)$ values are sufficiently high (i.e. more than .50). Also, all Significance of $\mathrm{F}$ values are less than .05 . Thus, the model fit is good.

- All Beta coefficients $\left(b_{1}\right)$ are positive. Thus, Governance rating has positive impact on financial performance of firm.

- All p-values are less than .05. Thus, Governance rating has significant impact on financial performance of firm.

- Thus, on the basis of these results, we reject the null hypothesis and accept the alternate hypothesis.

Thus, it can be inferred from statistical results that governance rating of company has a significant positive impact on its financial performance. Our research finding of positive impact of governance on financial performance is in conformance with existing research results of Van de Velde et al. (2005) [3]; Cremers and Nair (2005) [12]; Governance Metrics International and Byun (2006) [5]; and Eisenhofer (2010) [7]. These studies argue that good governance fosters good financial performance. We further find that ratings of company along employees-related and environmental dimensions also significantly influence corporate financial performance. The control variable firm size is also found to have significant impact on corporate financial performance. This result is in consonance with our expectation and with result of Guindry and Patten (2010) [13].

\section{Recommendations}

We find that corporate governance and corporate financial performance are correlated and governance rating of company has significant positive impact on its financial performance. This research finding may support decision of company to improve its governance structure. Companies should strive to improve its performance along indicators of good governance - Leadership Ethics, Board Composition \& Independence, Executive Compensation, Transparency and Reporting, Stakeholder Engagement, and Compliance with law in true letter and spirit. Companies should understand that improving governance and sustainability performance is as important as improving the financial performance.

\section{Limitations of Study}

The present study is subject to certain limitations. Firstly, the sample size is small (i.e. 20 companies). Secondly, the time period of research is short (i.e. 2 years). Thirdly, market-based measures of financial performance have not been considered in this study. Lastly, the study does not consider control variables like age of firm, growth of firm, capital intensity, leverage, risk, R\&D intensity, industry type, etc.

The results of study should be interpreted in light of these limitations and the future researchers should attempt to overcome them while doing further research in this area.

\section{References}

[1] Pande, S. (2011). Does Good Governance Pay? Evidence from Around the Globe. Retrieved from http://dx.doi.org/10.2139/ssrn.1976772

[2] Brown, L. D., \& Caylor, M. L. (2004). Corporate Governance Study: The Correlation between Corporate Governance and Company $\begin{array}{llllll}\text { Performance. } & \text { Institutional } & \text { Shareholder } & \text { Services } & \text { (ISS). } & \text { Retrieved }\end{array}$ http://www.stybelpeabody.com/issscoresandshareholdervalue.pdf

[3] Van de Velde, E., Vermeir, W., \& Corten, F. (2005). Corporate social responsibility and financial performance. Corporate Governance, 5(3), 129-138. 
[4] Gompers, P., Ishii, J., \& Metrick, A. (2003). Corporate governance and equity prices. The Quarterly Journal of Economics, 118(1), 107-156.

[5] Governance Metrics International, \& Byun, S. J. (2006, September). Governance and Performance: Recent Evidence. Governance Metrics International. Retrieved from http://www.gmiratings.com/Performance.aspx

[6] Selvaggi, M., \& Upton, J. (2008). Governance and Performance in Corporate Britain. Report from the Association of British Insurers Research and Investment Affairs Departments.

[7] Eisenhofer, J. W. (2010). Does Corporate Governance Matter to Investment Returns?. Grant \& Eisenhofer P.A. Retrieved from http://www.gelaw.com/wp-content/uploads/2011/05/ART_004A_corp_governance_colorchart.pdf

[8] Core, J. E., Guay, W. R., \& Rusticus, T. O. (2006). Does weak governance cause weak stock returns? An examination of firm operating performance and investors' expectations. The Journal of Finance, 61(2), 655-687.

[9] Statman, M. D., \& Glushkov. (2009). The wages of social responsibility. Financial Analysts Journal, 65, 33-46.

[10] Azim, M. I. (2012). Corporate governance mechanisms and their impact on company performance: A structural equation model analysis. Australian Journal of Management, 37(3).

[11] Lopez, M. V., Garcia, A., \& Rodriguez, L. (2007). Sustainable development and corporate performance: A study based on the Dow Jones Sustainability Index. Journal of Business Ethics, 75(3), 285-300.

[12] Cremers, K. J., \& Nair, V. B. (2005). Governance mechanisms and equity prices. The Journal of Finance, 60(6), 2859-2894.

[13] Guidry, R. P., \& Patten, D. M. (2010). Market reactions to the first-time issuance of corporate sustainability reports: Evidence that quality matters. Sustainability Accounting, Management and Policy Journal, 1(1), 33-50. 